\title{
Impacts of climate variability on East African pastoralists: linking social science and remote sensing
}

\author{
Kathleen A. Galvin'1,2,*, Randall B. Boone', Nicole M. Smith², Stacy J. Lynn ${ }^{3}$ \\ ${ }^{1}$ Natural Resource Ecology Laboratory, ${ }^{2}$ Department of Anthropology, ${ }^{3}$ Department of Rangeland Ecosystem Science, \\ Colorado State University, Fort Collins, Colorado 80523, USA
}

\begin{abstract}
In this paper we review the effects of the 1997 drought and the 1998 El Niño rains on Maasai herders in northern Tanzania and explore with satellite data the degree to which we can expand the spatial scale of the analysis. Hierarchical cluster analyses of regional vegetation biomass trends are used and are associated with the results of surveys conducted among the Maasai. The methods attempt to extend local-level survey data to landscape and regional scales. We were able to link the household production information to clusters of vegetation biomass, thus expanding the scale of the analysis. The analysis demonstrates the potential for spatial generalizations from an understanding of social processes at the local level for policy for mitigation and adaptation for dealing with climate variability.
\end{abstract}

KEY WORDS: Social science $\cdot$ Remote sensing $\cdot$ Climate variability $\cdot$ East Africa $\cdot$ Pastoralists

\section{INTRODUCTION}

East Africa, which includes much of Sudan, Ethiopia, Somalia, Kenya, Tanzania and Uganda, is home for hundreds of thousands of pastoralists. Pastoralists, with their herds of cattle, sheep, goats and in some regions camels, live in the dryer areas of the region. Rainfall seasonality affects livestock production and the livelihoods of these people. East African rainfall is bimodal with short rains occurring in October and November and long rains beginning in February or March and ending in May (Nicholson 1993, 1994, Ellis \& Galvin 1994). This pattern varies across the region, with uncertainty of the rains increasing in dryer zones. Despite this uncertainty pastoralists have diverse strategies to maintain livestock production. This is important as pastoralists are responsible for providing a major portion of the livestock to the markets in the region (Ensminger 1992, Kerven 1992).

*E-mail: kathy@nrel.colostate.edu
Much of East Africa experienced severe drought in 1997. This was followed by the El Niño rains beginning in October 1997. The short rains were replaced by heavy storms and floods (Government of Kenya Meteorological Services 1998). The rains continued through March 1998, when the long rainy season normally begins, and then continued through May. The long duration and high levels of rainfall damaged the region's infrastructure, agriculture, and caused health problems for both people and livestock. Livestock diseases such as blue tongue increased in the area. More than 4000 people died due to flooding. Incidence of diseases such as malaria and cholera increased. Cereal crops (maize, wheat) rotted in the fields and prices increased (Horn of Africa Review 1997, World Meteorological Organization 1998). Production of coffee and tea, very important export crops in the region, was severely reduced.

Tourism was severely curtailed due to infrastructure problems. Roads developed huge potholes, were flooded and sometimes were washed away. Damaged roads curtailed transportation, and costs of moving 
materials and food rose steeply (Government of Kenya Meteorological Service 1998, Washington Post 1998). Pastoralist informants in northern Tanzania stated that their normal routes to Kenyan livestock markets were flooded, which led them to resort to shipping their cattle by trucks using alternate routes. This was expensive and reduced their profit margin.

However, several sources reporting on the effects of the El Niño suggested that herders had 'lots of grass' for their cows, and that hunger among this segment of the population would be low (Government of Kenya Meteorological Service 1998, Washington Post 1998). In contrast, others reported that thousands of livestock died in Somalia alone as a result of flooding (Africa News 1997, ICRC 1997). Regional food security, for both pastoralists and others in the region was said to be precarious (Nabakwe 1999, Ngugi 1999).

In this paper we review the effects of the 1997 drought and the El Niño rains on Maasai herders in northern Tanzania and use satellite data to generalize our results over the region. Specifically the goals here are to scale up from the household to the region using analyses of household responses to climate and to discuss the relationships between household variables (livestock sales) to climate that the scaling-up suggests. A new method was required to enable us to scale up effects from households to the region.

Weather patterns during 1997 and 1998 were not typical; 1997 was a dry year and 1998 an exceedingly wet El Niño year (Fig. 1). We analyzed regional vegetation patterns in 1997 and 1998 and related these to Maasai responses to climate variability. Hierarchical cluster analyses of regional vegetation biomass trends were used, and were associated with the results of household surveys conducted among the Maasai. The methods attempt to extend local-level survey data to landscape and regional scales. Whereas social science has made great progress in understanding how households and communities make decisions, we rarely know to what extent the results may be generalized, and to what region. That is the value of linking household data with remotely sensed information.

\subsection{East African pastoralists}

Arid and semi-arid lands cover nearly two-thirds of the African continent. The majority of African livestock and more than 50 million people who are dependent on livestock and dryland agriculture reside in these dry zones. Climate variability is characteristic of all drylands, but in Africa it is particularly potent. This precipitation variability influences ecosystem dynamics and thus exerts a major influence on human lifestyles and land use patterns.

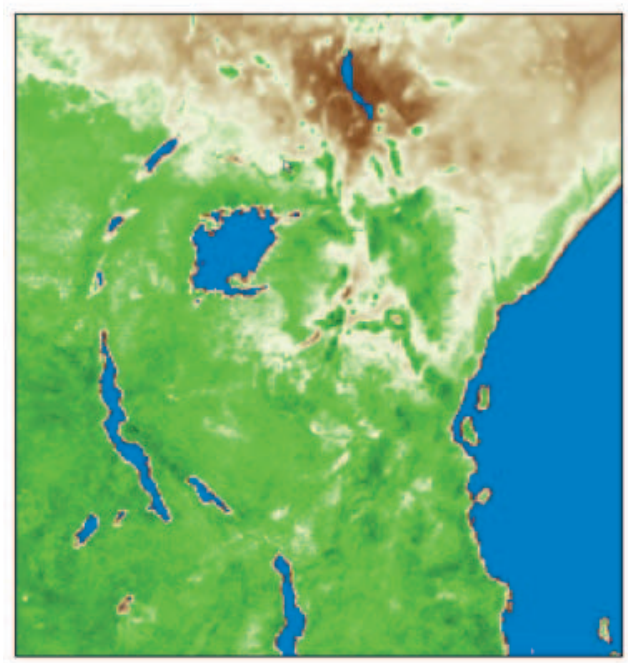

a.

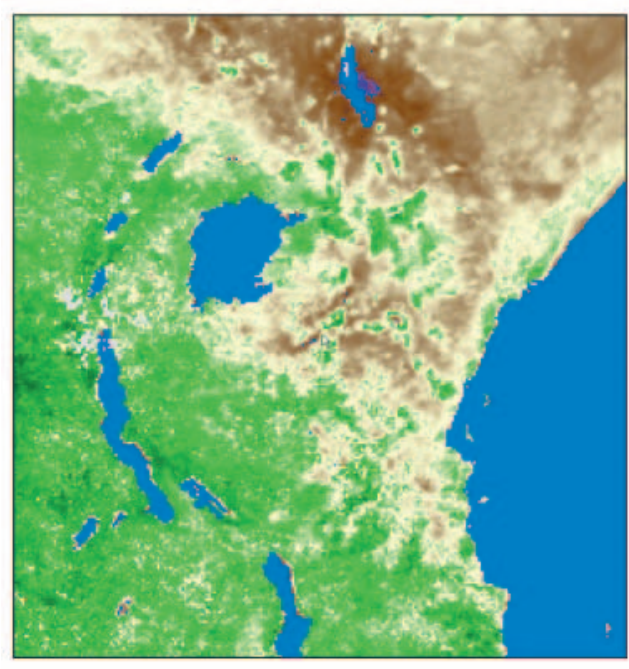

b.

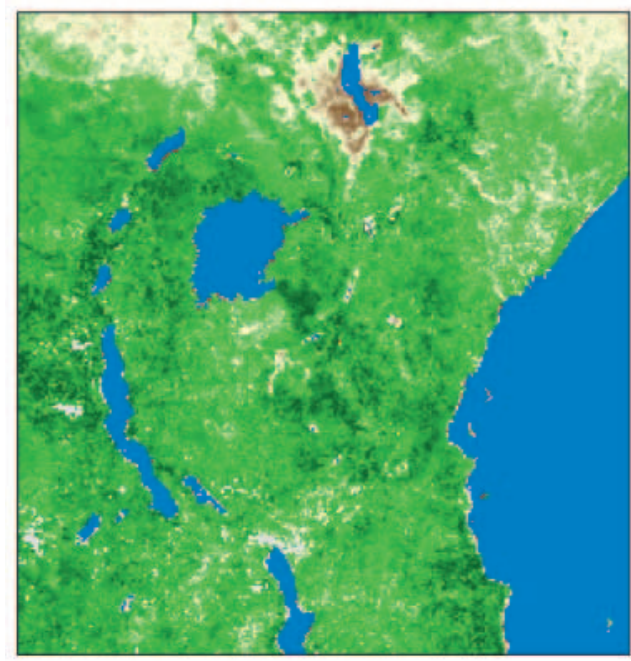

C.

0

$-0.33$

$-0.66$

Water

No data

Fig. 1. Vegetation biomass in East Africa, showing (a) a longterm pattern (1987-1996) for January, (b) January 1997, and (c) January 1998. NDVI values can range from -1 to 1 . The scale here extends from low biomass, brown $(-0.66)$, to high biomass, very green (1.0) 
Climate variability, by affecting ecosystem structure and function, has always influenced African livestock production and rainfed agriculture production. Pastoralists and agro-pastoralists depend directly and indirectly on the products of their livestock, so they have developed multiple coping mechanisms to deal with drought. These include keeping diverse species of livestock, movements of species-specific and production-specific livestock herds over large areas, emigration out of the pastoral system until the perturbation passes, economic diversity, and even allocating seasonal and drought-induced nutritional stress among those community members better able to cope with it (Galvin 1988, 1992, Galvin et al. 1994). Rain-fed agriculturalists diversify with livestock and have close economic ties to pastoralists and markets. These strategies are opportunistic and flexible, contingent upon existing conditions.

This combination of stabilizing strategies - large spatial scale of exploitation, demand reduction through emigration, economic diversity and specific food and nutritional stress allocation - has become constrained in this century due to 2 major factors: an increasing human population along with a stable or declining livestock population and a decreasing land use area (Little \& Brokensha 1987, Grandin 1988, Galvin 1992, Fratkin 1997). Pastoral and agricultural populations have grown, but livestock populations have fluctuated rather than expanded. East African pastoralists, for example, have been unable to expand livestock holdings due to such factors as disease epidemics, recurring droughts, and intertribal raiding. In addition, access to large amounts of land has been lost. Better watered dry season ranges have been lost to both colonial and African agriculturalists, to game parks, and to conservation areas. Pastoralists have taken up agriculture in an effort to meet their increasing food demands at the same time as agropastoralists have expanded cropping into more marginal areas (Sperling \& Galaty 1990). Fallow periods have shortened and fallowed areas have decreased.

Massive food shortages are projected for sub-Saharan Africa in the next quarter century based on current rates of population expansion and food production; the result has been further increases in livestock and agricultural intensification in arid and semiarid lands. Thus, with increasing population pressure on a declining and highly variable resource base, human vulnerability to drought and floods has increased.

Pastoralists and agropastoralists have, in the past, adapted very well to climate variability. However these populations have become vulnerable to climate variability in large part because their strategies for coping with climate variability have become constrained. An extensive spatial scale is a prerequisite for a successful pastoral system where droughts are frequent. Agriculture must be conducted with a diversity of other economic options. Opportunistic management practices are the rule (Sandford 1983, Behnke et al. 1993). Furthermore, developing strong interactions with the national economy through viable marketing systems is necessary.

\subsection{Maasai pastoralists}

Since the early 1990s conservation and human ecology has been the focus of interdisciplinary research in the Ngorongoro Conservation Area, Tanzania, where Maasai pastoralists live with a diverse and concentrated wildlife population. This joint-use area has come under increased scrutiny due to the perception that the quality of life is deteriorating for the Maasai while habitat degradation is increasing. We studied ecosystem structure, human land use and human welfare in Ngorongoro and have completed a comparative study of Maasai living outside Ngorongoro (Fig. 2). The Maasai of the adjacent Loliondo Game Controlled Area are

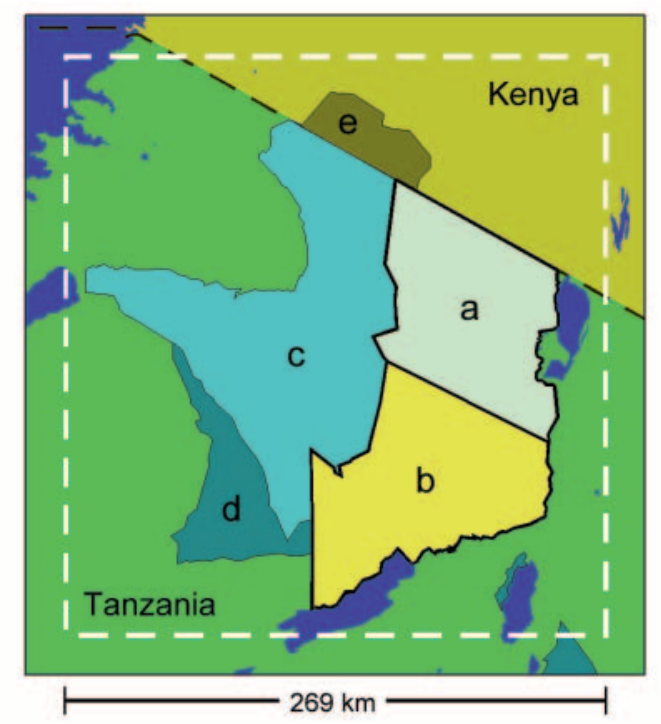

$$
\begin{aligned}
& \text { a - Loliondo Game } \\
& \text { Controlled Area } \\
& \text { b - Ngorongoro } \\
& \text { Conservation Area } \\
& \text { c - Serengeti National Park } \\
& \text { d - Maswa Game Reserve } \\
& \text { e - Masai Mara Game Reserve }
\end{aligned}
$$

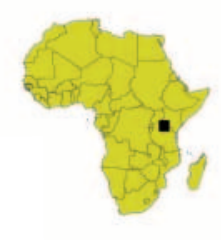

Fig. 2. The study region, with the area used in cluster analysis marked with a dashed box. The Loliondo Game Controlled Area (a) and the Ngorongoro Conservation Area (b) were the regions in this study 
not restricted by conservation policy, and all human activities, with the exception of unlicenced hunting of game animals, are allowed (Mwalyosi 1992). In contrast, the Maasai of Ngorongoro have been constrained by conservation policy for over $50 \mathrm{yr}$. Conservation policy has imposed a number of restrictions on Maasai land use, including restricting grazing areas and limitations on cultivation.

As in the case with other East African pastoralists, the Maasai have experienced increasing pressures on their lifestyle. In response to these changes, the pastoral economy has undergone and is undergoing intensification and diversification (Sperling \& Galaty 1990, Smith 1999). The Maasai have responded in one way to these pressures by taking up agriculture. Traditionally, Maasai did not practice agriculture on a regular basis, and relatively low levels of exchange for agricultural products characterized their economic system. These patterns are changing as livestock holdings have decreased (Grandin 1988).

The Maasai traditional diet consisted of milk, meat and blood from their livestock herds (Nestel 1986, Homewood 1992). Now there is an increase in the consumption of non-pastoral foods such as maize meal, tea and sugar (Arhem 1985, Homewood et al. 1987, Talle 1987). Cash is required to buy these goods and to purchase inputs for livestock and agricultural production (Grandin 1988, 1991). Other cash expenditures include household utensils, school fees, hospitalization, veterinary drugs and breeding stock (Talle 1987, Smith 1999). The increased dependence of pastoralists on cash income has resulted in the incorporation of cultivation into their economic strategies wherever rainfall and ecological factors permit (Rigby 1985).

\section{METHODS}

\subsection{Household interviews}

Forty-nine in-depth household interviews were conducted - 23 in Loliondo and 26 in Ngorongoro-from May through December 1998 (Fig. 3). Research data were collected from June through September 1998 using ethnographic research techniques comprised of formal and informal interviews (McCracken 1988, Jorgensen 1989). The questionnaire and interview process provided a comprehensive overview of the economic operation of the household. Data were collected on household composition, income and expenditures, livestock numbers, agricultural production, and marketing, for 1997 and 1998 (Smith 1999).

There are several strengths to the ethnographic field methodologies used in this research. The hallmark of ethnography is that the 'research attempts to un-

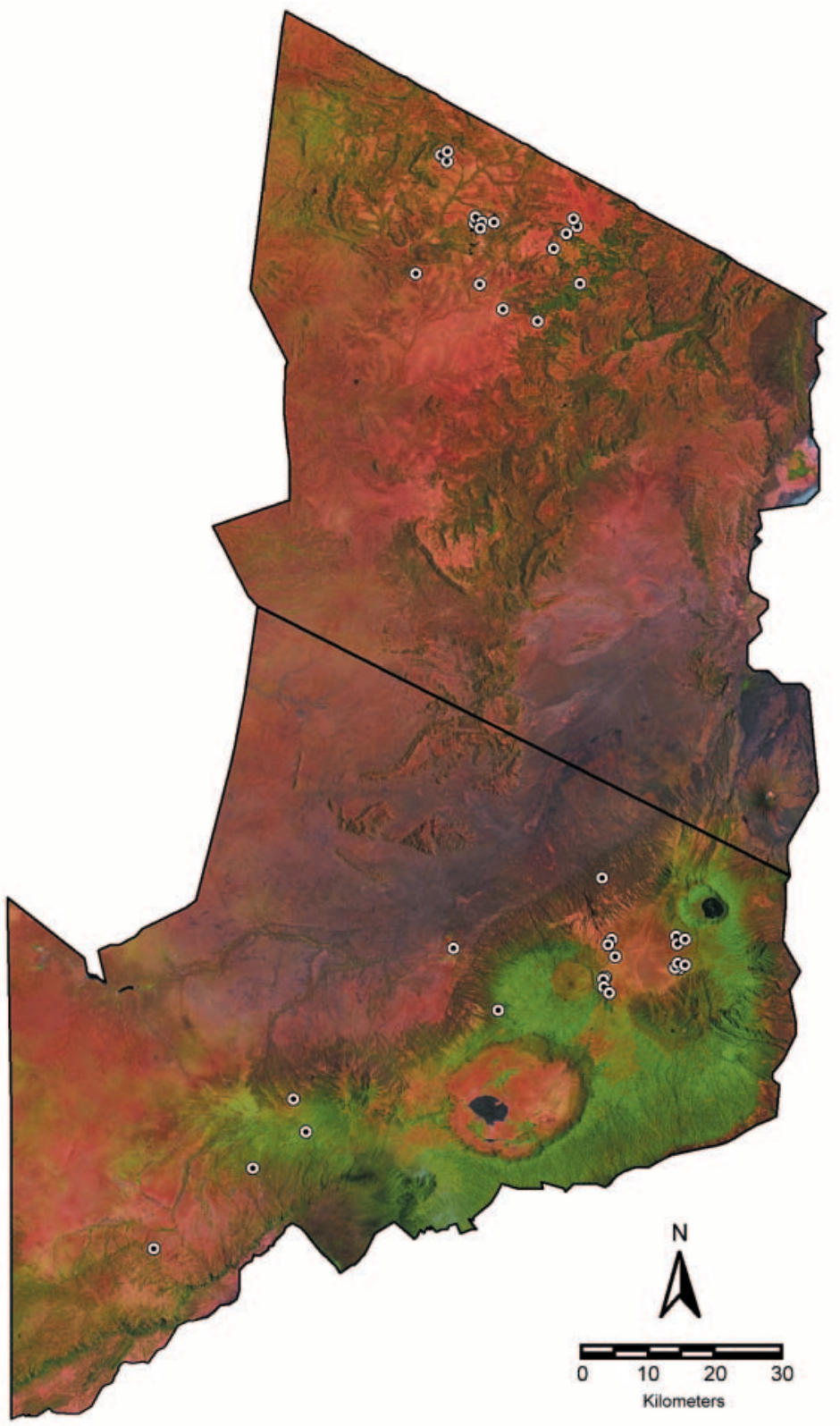

Fig. 3. Locations of household interviews $(n=46)$, overlaid upon a 1993 Landsat Thematic Mapper satellite image to provide context

derstand a culture from the insider's point of view' (MacLeod 1987, p. 8). This research benefited from ethnographic procedures because: (1) direct personal involvement with informants fostered a rapport that encouraged informants to more fully explore their thoughts and feelings about the questions posed; (2) the verbal behavior of informants could be observed and used to elicit further discussion; and (3) by living in the community, even for a short period of time, a greater sense of Maasai culture could be ascertained (Agar 1996).

As actual recall data on income and expenditures is often unreliable (Fowler 1993), economic data were 
gathered by rank ordering income and expenditure items. Income and expenditure data were assigned an arbitrary ranking of importance to create an index of importance of each income and expenditure source to the household. The scores were converted to a percentage to provide an index of importance. Livestock related questions included information on herd composition and number, slaughter and consumption data and sales. Percent of herd sold was estimated based on numbers sold relative to total herd size.

The spatial locations of interview households were determined with a global position system (GPS) unit (Fig. 3). These locations were projected to a common coordinate system, and joined with the data representing interview results. The locations of 4 of the 49 households were not identified with a GPS, but were near $(\sim 800 \mathrm{~m})$ other households interviewed.

From the household data collected, variables for this study were selected that: (1) appeared to demonstrate spatial trends in response to 1998 rainfall, and (2) we hypothesized would be associated with broad-scale vegetation biomass patterns. These included: area cultivated; cattle numbers sold; numbers of sheep and goats sold; cattle slaughtered; sheep and goats slaughtered; and the differences between the livestock variables, subtracting the 1998 value from the 1997 value (Table 1). Whereas we related all these data to the maps derived from the cluster analyses only 2 were significant to vegetation patterns: the number of sheep and goats sold in 1998 and the difference in sheep and goats sold between 1997 and 1998.

\subsection{Satellite data}

A general goal for us was to create a method that would allow the effects of changes in rainfall patterns on pastoralist households to be generalized to regions. We sought a method that would be inexpensive, could be used anywhere, would allow frequent updates, was spatially reasonably detailed, and would not require

Table 1. Household data used in analysis

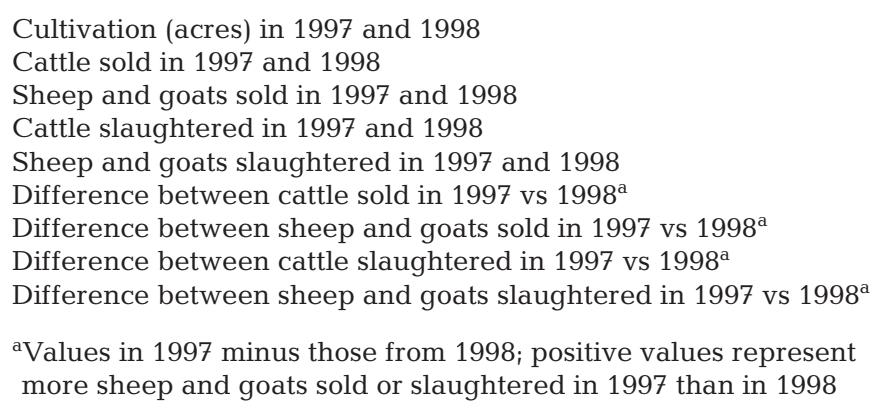

extensive field surveys. We hypothesized that El Niño effects on Maasai were related to the patterns of response in vegetation dynamics. The increase in precipitation associated with El Niño increases vegetation biomass and vigor (Anyamba \& Eastman 1996, Kogan 1998), and so we assessed the relationship between changes in Maasai livestock and crop production and vegetation biomass trends.

To generalize interview results, normalized difference vegetation indices (NDVI), derived from AVHRR (Advanced Very High-Resolution Radiometer) weather satellite images, representing regional vegetation biomass dynamics, were used. These images represent vegetation biomass and vigor at the surface of the plant canopy (Avery \& Berlin 1992) and are used widely. NDVI images from satellites are available world-wide, free, updated every $10 \mathrm{~d}$, spatially detailed relative to a regional scale, and extremely sensitive to rainfall patterns; they provide an index to green vegetation biomass, which is of profound importance to pastoralists.

NDVI data from 2 programs were used in the analyses, representing up-to-date coarse $(7.6 \mathrm{~km})$ resolution data and fine $(1 \mathrm{~km})$ resolution data from a limited time period, 1992-1996. We hypothesized that the vegetation patterns for a dry year (1997) and a wet year (1998) would be correlated to long-term vegetation patterns, linking the 2 data sources. That is, if the 1997 and 1998 coarse-scale data were correlated with long-term coarse-scale data, we could be more confident in our use of the available $1992-19961 \mathrm{~km}^{2}$ data to relate to 1998 vegetation biomass patterns. Long-term coarsescale data consisting of 36 images $\mathrm{yr}^{-1}$, spanning from 1986/1987 (i.e., November 1986 to October 1987 representing the start of the wet season to the end of the dry season) to $1997 / 1998$, were downloaded from the USGS African Data Dissemination Service (USGS 1999) and incorporated into the Geographical Information System (GIS). To represent long-term biomass patterns, the data from 1986/1987-1995/1996 were used to calculate thirty-six $10 \mathrm{~d}$ mean responses. Analogous sets of images were created for 1996/1997 (a dry year) and 1997/1998 (a wet El Niño year).

We also created a suite of $1 \mathrm{~km}$ resolution NDVI images for the same thirty-six $10 \mathrm{~d}$ periods used in the previous program, from images acquired from the Global Land $1 \mathrm{~km}$ AVHRR program (USGS 1998). These data have a resolution higher than the $7.6 \mathrm{~km}$ data and are more complicated to produce, distribute, and store. They were therefore only available for the period noted, from April 1992 to May 1996, with some periods missing (all of 1994 was missing, for example). The entire collection for East Africa was downloaded and thirty-six $1 \mathrm{~km}$ res- 
olution mean biomass patterns were calculated and incorporated into the GIS. A subset of these data representing the Greater Serengeti Ecosystem $\left(1^{\circ} 7^{\prime} \mathrm{S}\right.$, $33^{\circ} 48^{\prime} \mathrm{E}$ to $3^{\circ} 42^{\prime} \mathrm{S}, 36^{\circ} 10^{\prime} \mathrm{E}$ ) was used in cluster analyses, including $1 \mathrm{~km}^{2}$ cells totalling 75790 (see Fig. 2). From the clustered data, a further subset of $34456 \mathrm{~km}^{2}$, including Ngorongoro and Loliondo $\left(1^{\circ} 34^{\prime} \mathrm{S}, 34^{\circ} 47^{\prime} \mathrm{E}\right.$ to $3^{\circ} 42^{\prime} \mathrm{S}, 36^{\circ} 6^{\prime} \mathrm{E}$ ) was used in generalizing household interviews.

\subsection{Cluster analyses and generalizing the interviews}

The general methods are outlined in a series of schematics. NDVI images are represented in Fig. 4 as two 9-cell images representing 2 time periods. These images cover the same area spatially, so each pixel has multiple values associated with it, one for each time slice, representing a biomass profile. The biomass profiles are used in a cluster analysis, represented in the middle graphs by 2 dimensions corresponding to the 2 images or time periods. Here, a dry barren cell would be near the origin of the graph, with low biomass in

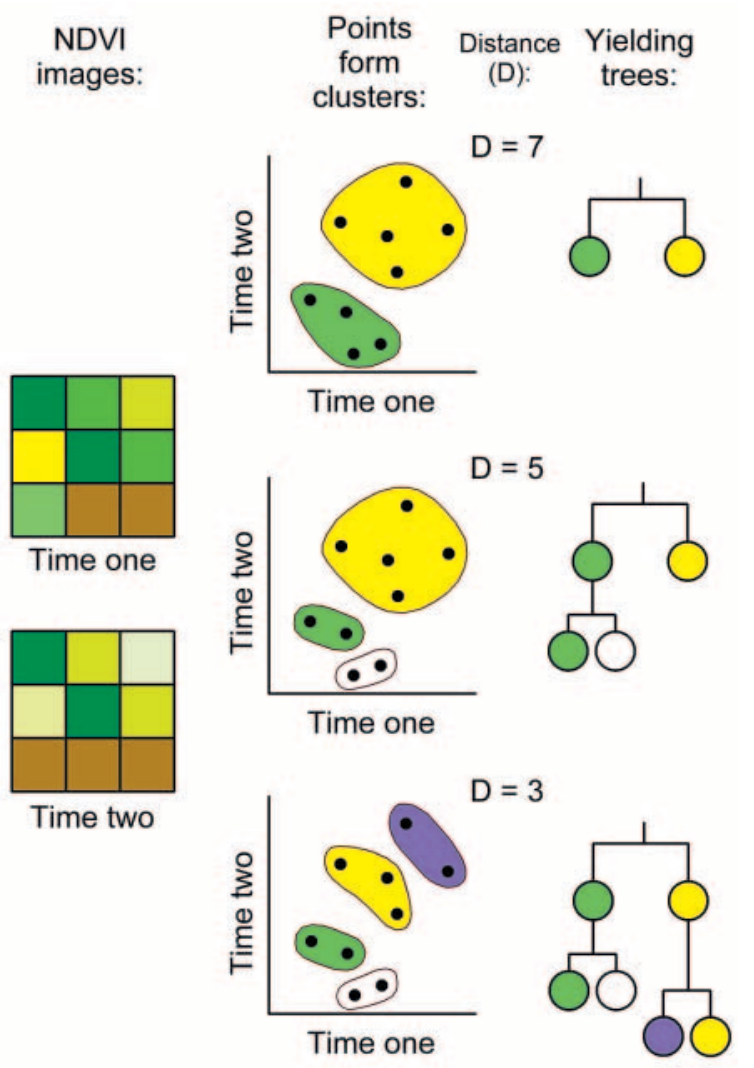

Fig. 4. A schematic demonstrating how hierarchical trees were formed. NDVI indices were used as dimensions of a cluster analysis (2 dimensions in this figure, 36 dimensions in practice) both periods. An evergreen forest cell would be near the upper left of the graph, with high biomass in both periods. Lastly, a deciduous forest cell might be near the right side of the graph and high in biomass at Time 1, but near the bottom of the graph and low in biomass at Time 2, after leaf-fall.

Hierarchical cluster analysis entails taking the number of cells, $n$ (here considered clusters with 1 cell each), and calculating the distance between every possible pair of clusters. In essence, the 2 clusters that are closest to each other are merged, yielding 1 fewer cluster. This is represented near the bottom of Fig. 4 (right) for some distance $(D)$ equal to 3 , with the 9 cells classified into 4 clusters, based upon the average distances between the clusters. The distance at which they merged is recorded as well, allowing a hierarchical tree to be created, showing the relationships between clusters. From both the graph and tree, we see that the cells that make up each cluster share a biomass profile more alike to that of other cells within that cluster than to those of cells in other clusters. The

$$
\begin{array}{lll}
\text { Distance } & \text { Clustered } & \text { Map } \\
\text { (D): } & \text { pixels at: } & \text { to: }
\end{array}
$$
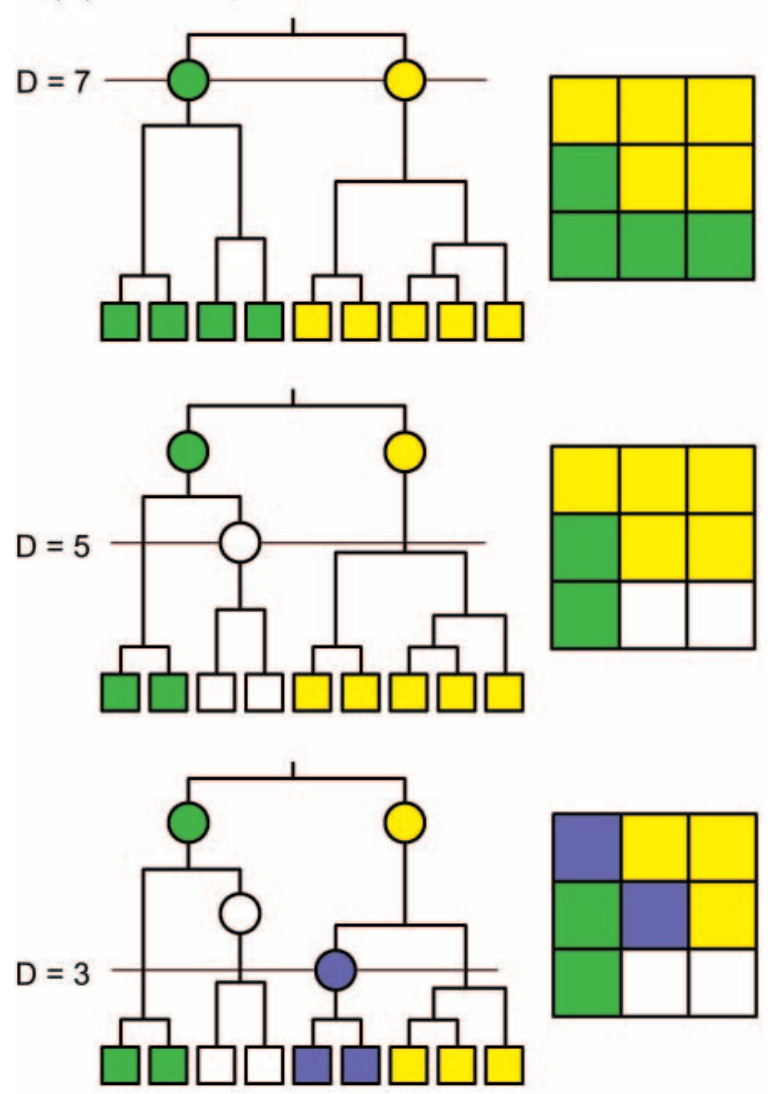

Fig. 5. Clusters may be mapped at different distances within the hierarchical tree. As distance decreases, more smaller clusters are mapped 
process repeats, measuring distances between clusters and merging those that are closest, with the number of clusters reduced by 1 during each cycle (e.g., Fig. $4, D=5$ and $D=7$ ). The process stops when the entire data set has been assigned to a single cluster (Anderberg 1973).

A hierarchical tree relating biomass profiles for cells may seem of limited use, but the geographic position of each cell is retained. We can therefore represent spatially how biomass patterns are arranged. In Fig. 5, for example, with $D=7,5$ cells in the northern part of the map form a cluster-judging from the top graph in Fig. $4(D=7)$, these cells are generally high in biomass. Four cells at the southern part of the 9-cell map cluster together-these cells are generally low in biomass. Because the tree is hierarchical, we can inspect the pattern of clusters at $D=5$ as well (Fig. 5, middle), and see that cells in the southeast cluster together. Inspecting the graph in Fig. 4, we find these cells have moderate biomass at Time 1, and very low biomass at Time 2 . Analogous logic may be used at $D=3$, identifying 2 cells that form a cluster with very high biomass in both time periods (Figs 4 \& 5). In general then, these methods yield non-overlapping clusters over an entire region for a given distance and, across decreasing distances, clusters divide hierarchically (Omi et al. 1979, Hargrove \& Luxmoore 1997, Krohn et al. 1999), depicting more subtle differences in biomass profiles with each division of clusters.

In this study, for the $1 \mathrm{~km}$ NDVI data, each of the 75790 cells was assigned a unique identifier. These identifiers were combined with the value of the cell for each of the thirty-six $10 \mathrm{~d}$ periods, creating a mean green biomass profile through the year for each of the cells, and yielding a cluster analysis with 36 dimensions. Often in cluster analyses the variables used are transformed to approach normality and the same variance. We did not transform the NDVI data; they are normalized and so are on the same scale and have similar variances. These data can vary from normality, but not to a great extent (Eklundh 1998). Cluster analysis was conducted using ClustanGraphics (Clustan Limited, Edinburgh, Scotland; Wishart 1999). Average linkage distance measures in clustering was used, which was also most effective when several clustering methods were contrasted in related analyses (Krohn et al. 1999). In average linkage, the average distance between all the points within the clusters compared is used to represent distance (Anderberg 1973, Wishart 1999).

From the cluster analysis, the tree showing the hierarchical relationships of clusters was processed in a custom Visual Basic program (Microsoft Corp., Redmond, WA). The program created a series of 209 maps of clusters at various levels of the hierarchy, and saved the maps as image files. Map files were then incorporated into ARC/INFO (Environmental Systems Research Institute, Redlands, CA) as grids.

These maps spanned a gradient, from the entire region being comprised of 2 clusters, to the region containing 75790 clusters (i.e., one $1 \mathrm{~km}$ square cell per cluster). To determine the appropriate cluster map to use within this gradient, a series of 1-way analyses of variance (ANOVA) between cluster identifiers and interview data were conducted (Wilkinson 1990). The schematic in Fig. 6 provides an example. With too few clusters $(D=7)$, different El Niño effects occur within the same cluster, and the model is under-fitted. With too many clusters $(D=3)$, a given El Niño effect occurs in more than 1 cluster, that is, a given effect is being related unnecessarily to more than 1 biomass profile, and the model is over-fitted. Ideally ( $D=5$ in Fig. 6),

\section{Given effects of El Niño:}

$$
\begin{aligned}
& \text { ○ Large } \\
& \text { ○ Moderate } \\
& \text { ○ Small }
\end{aligned}
$$

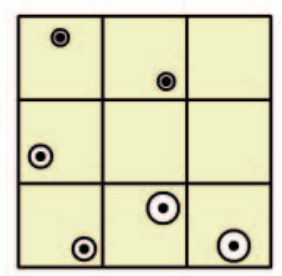

\section{Distance \\ (D):

$$
\mathrm{D}=7
$$

Some discrimination: Under-fitted

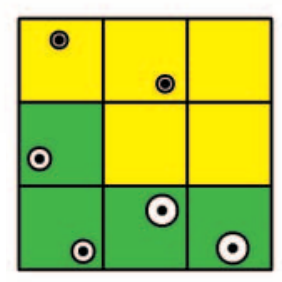

$$
D=5
$$

Perfect discrimination

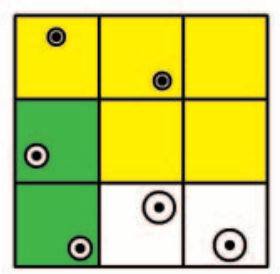

$$
\mathrm{D}=3
$$

Loss of discrimination: Over-fitted

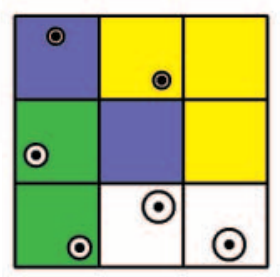

Fig. 6. The discrimination of interview data determines which distance in the cluster hierarchy is used 
each given El Niño effect would fall within a single cluster, yielding perfect discrimination. In practice, the optimum fit was identified by plotting the degree of discrimination in the data (represented by $\mathrm{p}$ values in the ANOVA) against the distance at which clusters were mapped. Most such graphs had poor discrimination with few clusters or with many clusters, as expected, but had an optimum point or points where the data were described the best (though not necessarily to a significant degree).

For variables with significant discrimination, we classified the mean response variable from the socioeconomic interviews within each cluster to 4 levels for mapping purposes. The clusters with interview data were then shaded based upon the response variable. Any clusters without interview data were shown in a neutral color; we cannot infer the effects of El Niño on areas within those clusters because interviews were not conducted with people living there. Generally, the regions without interviews contained few Maasai with permanent residences, or the interviewers were unable to reach the areas due to lack of roads or tracks.

\section{RESULTS}

\subsection{Maasai economy 1997-1998}

The Maasai economy is based on livestock production, and where possible and permitted, agriculture is increasing as a component of household income. Livestock sales in these sites was however, the overwhelming source of income, providing $88 \%$ of total income to the Loliondo Maasai and $83 \%$ to Maasai in Ngorongoro, followed far behind by crop sales $(5 \%$ for Loliondo and 14\% for Ngorongoro) (Smith 1999, Galvin et al. in press). The long rains of 1998 were hard on livestock herds. Cattle deaths from disease as a percentage of total herd size was about $11 \%$ in Loliondo and $29 \%$ in Ngorongoro. Disease also accounted for more small stock (sheep and goats) deaths in Ngorongoro $(15 \%)$ than in Loliondo $(11 \%)$. High disease incidence may account for more livestock sales in Ngorongoro than in Loliondo (Table 2). However, in the previous drought year of 1996/1997, an even higher percentage of the livestock herd was sold, the pro-

Table 2. Livestock sold in 1997 and 1998 as a percentage of the total herd

\begin{tabular}{|c|c|c|c|c|}
\hline & \multicolumn{2}{|c|}{ Ngorongoro } & \multicolumn{2}{|c|}{ Loliondo } \\
\hline & 1997 & 1998 & 1997 & 1998 \\
\hline Cattle & 11 & 3 & 4 & 2 \\
\hline Small stock & 14 & 5 & 3 & 1 \\
\hline
\end{tabular}

Table 3. Agricultural plot size and yields in 1997 and 1998

\begin{tabular}{|lcccc|}
\hline & \multicolumn{2}{c}{ Ngorongoro } & \multicolumn{2}{c|}{ Loliondo } \\
& 1997 & 1998 & 1997 & 1998 \\
\hline $\begin{array}{l}\text { Acres cultivated per } \\
\text { household }\end{array}$ & 2.1 & 2.6 & 3.7 & 3.6 \\
$\begin{array}{l}\text { Yield (kg) per } \\
\text { household }\end{array}$ & 47 & 1444 & 1351 & 1469 \\
$\begin{array}{l}\text { Yield (kg) per acre } \\
\text { Yield (kg) per person }\end{array}$ & 25 & 476 & 344 & 485 \\
& 5 & 86 & 107 & 191 \\
\hline
\end{tabular}

ceeds from which were used primarily to purchase food.

Agricultural plot size did not change within each area between years but the Ngorongoro harvest was very low in 1997, making it virtually impossible for people to live from their harvests (Table 3). It is no wonder that under these circumstances people sold a higher percentage of their livestock herds in 1997 to feed themselves.

\subsection{Generalizing results to the region}

Although interviews were conducted at 49 households during 1997 and 1998, only 46 had adequate data for our use. These households were well distributed between Loliondo ( $\mathrm{n}=22$ households) and Ngorongoro ( $\mathrm{n}$ $=24$ ). Because these data were collected without plans for regional analyses, some households were close to each other. The 46 households were located within thirty-four $1 \mathrm{~km}$ cells. Given this, the maximum number of clusters that contained interview data was 34 .

The hypothesis that the extreme vegetation patterns of 1997 and 1998 were correlated with long-term vegetation patterns was upheld. When 1997 NDVI data were compared to long-term data (1987-1996), the agreement was high, with a correlation coefficient of $r>0.86$ for comparisons between monthly means. A comparison between 1998 NDVI data from the El Niño year and long-term patterns yielded similar correlations (e.g., $r>0.80$ ). The pattern of vegetation change across space was correlated through time, which lends support to the use of long-term (1992-1996) $1 \mathrm{~km}$ resolution NDVI data in cluster analyses and relating it to the 1998 El Niño weather event.

In the search for optimum agreements between the 9 household variables analyzed and the cluster maps, most graphs showed the predicted behavior. A maximum discrimination was demonstrated at intermediate distances down the tree of cluster hierarchies. Clusters were related significantly $(p<0.05)$ to only 2 of the variables, however. The numbers of sheep and goats sold in 1998 were significantly related to differences in 


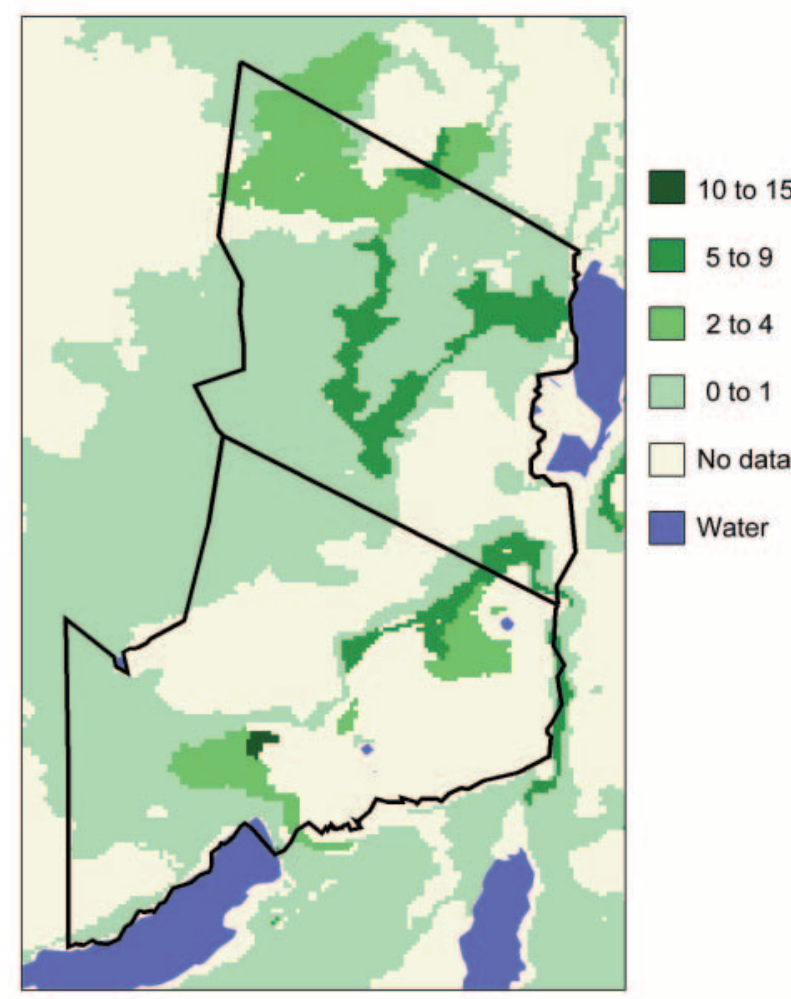

Fig. 7. Sheep and goats sold in 1998. Colors depict intensity of sales

long-term vegetation patterns $\left(\mathrm{r}^{2}=0.60 ; \mathrm{p}=0.004\right)$ (Fig. 7). Fifteen vegetation clusters included interview data at the optimum distance in the hierarchy $(D=79)$. Thus it is possible to generalize up to the spatial scale covered by each cluster on the basis of the socioeconomic data gathered from households. Given the assumptions in our methods, of the $34456 \mathrm{~km}^{2}$ in our study area, $43 \%\left(5028 \mathrm{~km}^{2}\right)$ had Maasai with $<2$ goats sold in $1998,5 \%\left(1884 \mathrm{~km}^{2}\right)$ had residents with 2 to 4 goats sold, $4 \%\left(1258 \mathrm{~km}^{2}\right)$ had residents with 5 to 10 goats sold, while less than $1 \%\left(32 \mathrm{~km}^{2}\right)$ had residents with 10 to 15 goats sold. Almost $50 \%$ of the area (47\%) $\left(16254 \mathrm{~km}^{2}\right)$ contained no interview data. In general, Maasai living in the middle to low elevation regions of both Ngorongoro and Loliondo sold more goats during the wet El Niño year than those living on the low slopes or in the mountainous areas (Lynn 2000).

Fig. 8 applies the same analysis to the difference in sheep and goats sold between 1997 and 1998. Small livestock in Ngorongoro were sold more often during the 1997 drought than animals within Loliondo. Changes in the number of sheep and goats owned between 1997 and 1998 was related significantly to long-term vegetation patterns $\left(r^{2}=0.43 ; p=0.048\right)$. The cluster map that best discriminated the change in numbers of small livestock had 13 clusters $(D=88)$. In

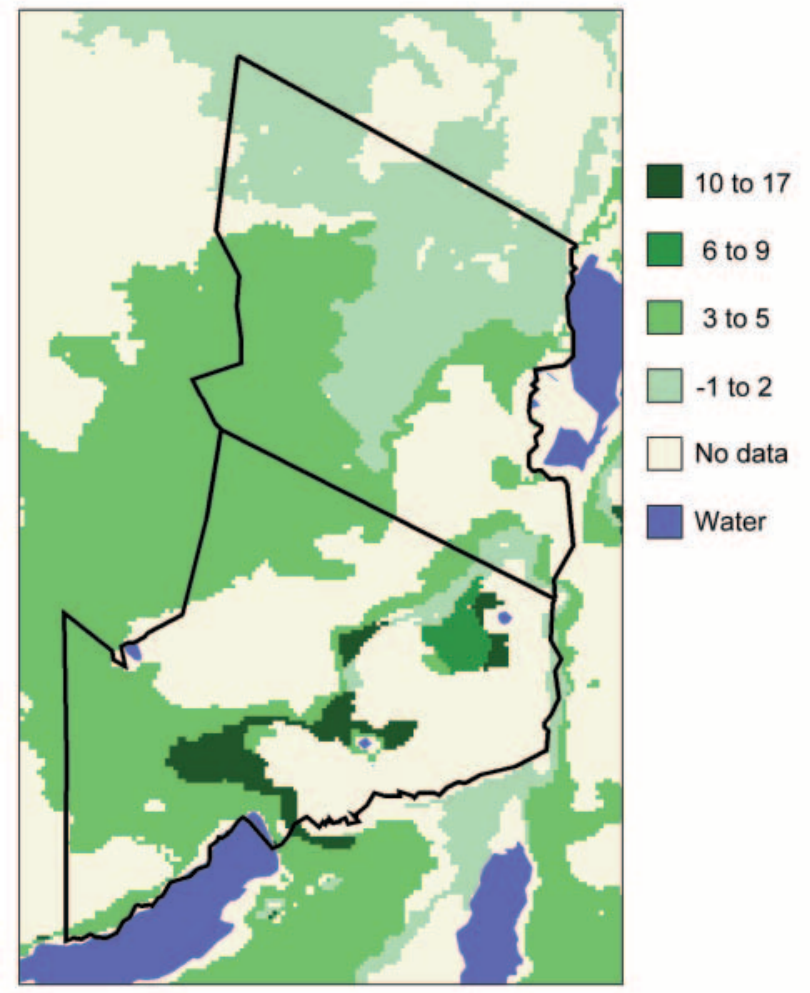

Fig. 8. Sheep and goats sold in 1997 minus those sold in 1998. Colors depict the difference between sales in the 2 years

contrast to the similar distribution in the sale of sheep and goats in 1998, the change in numbers sold from 1997 to 1998 was dramatically different between Loliondo and Ngorongoro (Fig. 8). Maasai in Ngorongoro sold many more goats in response to drought than did Maasai in Loliondo.

The results suggest that of the region $17 \%\left(5953 \mathrm{~km}^{2}\right)$ had Maasai with similar numbers of goats sold in both years, $34 \%\left(11630 \mathrm{~km}^{2}\right)$ had residents that sold 3 to 5 fewer goats in 1998 than 1997, while less than 1\% $\left(201 \mathrm{~km}^{2}\right)$ had residents that sold 6 to 9 fewer goats in 1998 than 1997 . About $2 \%$ of the area $\left(651 \mathrm{~km}^{2}\right)$ had residents that sold 10 to 17 fewer goats in 1998 than 1997, while $46 \%$ of the area $\left(16021 \mathrm{~km}^{2}\right)$ contained no interview data. These results suggest that over the region, the dry year, 1997, differentially affected households when contrasted with the wet El Niño year. In general, the drought led to many Maasai in Ngorongoro selling their small stock and may have left animals in poor condition. The El Niño year then led to higher small stock sales for those Maasai that live at mid elevations, likely due to increased disease incidence and low temperatures among a livestock population not used to either (as opposed to those livestock populations that are adapted to high elevation) (Smith 1999, Lynn 2000). 


\section{CONCLUSIONS}

We were able to link household production information to clusters of vegetation biomass, thus expanding the scale of our household analysis using quantitative methods. We could ask the following question: How does this improve our interpretation of land use? If we had conducted a household study on the impacts of El Niño, without the use of the satellite data, we would also have attempted to make generalizations up to larger spatial scales. However, the NDVI analysis brings more rigor to the process of generalization. By linking the satellite data with the household level information, we have gained the ability to map at a regional scale the distribution of the economic consequences of climate events that are meaningful to local communities over a much larger landscape than is otherwise possible. Use of either the social science data or the remotely sensed data alone would not provide as complete a picture as the combined data sets.

Much of the work linking social data and remote sensing data addresses land use change analyses. For example, Moran's (e.g., Moran \& Brondizio 1998) welldocumented studies of land-use/land-cover change dynamics following deforestation is an excellent example of this type of work. Moran and his colleagues explored the human forces driving land-use change. This and similar studies (cf. Rindfuss \& Stern 1998) have improved our understanding of the determinants of land-use change. Here we have explored the interaction between changes in vegetation, caused by climatic events, and human behavior. This is an important difference. As climate variability, such as El Niño events, increases in various regions of the world, it is important to understand how people are affected by such events and how they could better adapt to such events. Local-level process data are costly and time consuming to acquire, yet necessary. If we can generalize spatially from an understanding of social processes at the local level, then policy for mitigation and adaptation may be more appropriate.

Livestock keepers have options for dealing with climate variability, which work if it is possible for them to actually exercise them. The data here suggest many diseased animals were sold; herders could theoretically change key management practices by selling livestock earlier or stocking up on veterinary supplies before disease outbreaks. This could occur with advance warning of such events by governments and the livestock sector. Although theoretical benefits of forecasts are real, there are several social, economic, and political constraints that can prevent actions from being taken (Betsell et al. 1997, Stern \& Easterling 1999). Ability to respond to information depends on whether herders actually receive the information, believe it to be reliable and have the ability to change herding practices or add to management. Appropriate initiatives to reduce human vulnerability or to increase economic well-being must account for climate variability. New developments in climate forecasting can provide a basis for an 'early warning' for vulnerable populations in these regions whose agricultural and livestock production is dependent on the vagaries of rainfall.

Had this study been designed to specifically understand the relationship between social processes and regional vegetation patterns, we would have asked additional questions about climate impacts. We would also have sampled over a much broader spatial scale. Because we did not consider this when conducting fieldwork, our results are preliminary. Nevertheless, the methodology, though in an early stage, does show promise for linking the behavior of households to regional-scale patterns of remotely sensed vegetation data.

Human-environment interactions are iterative processes. Most people in the world structure their lives in concert with their environmental contexts. Many social science theories link behavior to the local context in which the household is located, and there are environmental consequences of social, economic and demographic processes. Remote sensing data combined with social science data on human behavioral processes have the potential to improve the understanding of these iterative processes.

Acknowledgements. This research was supported by the US National Science Foundation (BNS-9100132 and SBR9709762). This publication was also made possible through support provided by the Office of Agriculture and Food Security, Global Bureau, United States Agency for International Development, under Grant No. PCE-G-98-00036-00. The opinions expressed herein are those of the authors and do not necessarily reflect the views of the US Agency for International Development.

\section{LITERATURE CITED}

Africa News (1997) Heavy floods continue to wreak havoc in Horn, Kenya. AllAfrica Global Media, Washington, DC; available at www.africanews.org

Agar MH (1996) The professional stranger. Academic Press, New York

Anderberg MR (1973) Cluster analysis for applications. Academic Press, New York

Anyamba A, Eastman JR (1996) Interannual variability of NDVI over Africa and its relation to El Niño/Southern Oscillation. Int J Remote Sensing 13:2533-2548

Arhem K (1985) Pastoral man in the Garden of Eden. The Maasai of Ngorongoro Conservation Area, Uppsala Research Report in Cultural Anthropology, Uppsala

Avery TE, Berlin GL (1992) Fundamentals of remote sensing and airphoto interpretation. Macmillian Publishing, New York 
Behnke R, Scoones I, Kerven C (1993) Range ecology at disequilibrium. Overseas Development Institute, London

Betsell MM, Glantz MH, Crandall K (1997) Preparing for El Niño: What role for forecasts? Environment 39(10):6-13

Eklundh L (1998) Estimating relations between AVHRR NDVI and rainfall in East Africa at 10-day and monthly time scales. Int J Remote Sensing 19:563-568

Ellis J, Galvin KA (1994) Climate patterns and land-use practices in the dry zones of Africa. Bioscience 44(5):340-349

Ensminger J (1992) Making a market: the institutional transformation of an African society. Cambridge University Press, New York

Fowler FJ Jr (1993) Survey research methods, 2nd edn. Applied Social Research Methods Series, Vol 1. Sage Publications, London

Fratkin E (1997) Pastoralism: governance and development issues. Annu Rev Anthropol 26:235-261

Galvin KA (1988) Nutritional status as an indicator of impending food crisis. Disasters 12(2):147-156

Galvin KA (1992) Nutritional ecology of pastoralists in dry tropical Africa. Am J Human Biol 4:209-221

Galvin KA, Coppock DL, Leslie PW (1994) Diet, nutrition and the pastoral strategy. In: Fratkin E, Galvin KA, Roth EA (eds) African pastoralist systems: an integrated approach. Lynne Rienner, Boulder, p 113-132

Galvin KA, Ellis J, Boone RB, Magennis AL, Smith NM, Lynn SJ, Thornton $\mathrm{P}$ (in press) Compatibility of pastoralism and conservation? A test case using integrated assessment in the Ngorongoro Conservation Area, Tanzania. In: Chatty D, Colester M (eds) Displacement, forced settlement and conservation. Berghahn, Oxford

Government of Kenya Meteorological Service (1998) The ElNiño Rains of October 1997 to January 1998 in Kenya. Kenya Meteorological department, Nairobi; available at www.meteo.go.ke/pws/elnino.html

Grandin BE (1988) Wealth and pastoral dairy production: A case study from Maasailand. Human Ecol 16(1):1-21

Grandin BE (1991) The Maasai: socio-historical context and group ranchers. In: Bekure S, deLeeuw PN, Grandin BE, Neate PJH (eds) Maasai herding: an analysis of the livestock production system of Maasai pastoralists in Eastern Kajiado District, Kenya. ILCA Systems Study 4. ICLA (International Livestock Centre for Africa), Addis Ababa, p 21-39

Hargrove WW, Luxmoore RJ (1997) A spatial clustering technique for the identification of customizable ecoregions. Environmental Systems Research Institute International User Conference, July 8-11, Redlands, CA. Environmental Systems Research Institute, Inc, Redlands, CA; available at www.esri.com/library/userconf/proc97/HOME.HTM

Homewood K (1992) Development and the ecology of Maasai pastoralist food and nutrition. Ecol Food Nutrition 29: $61-80$

Homewood K, Rodger WA, Arhem K (1987) Ecology of pastoralism in Ngorongoro Conservation Area, Tanzania. J Agric Sci Camb 108:47-72

Horn of Africa Review (1997) Horn of Africa Review compiled by the UNDP-EUE, 6/1-7/31 1997. University of Pennsylvania, Philadelphia; available at www.sas.upenn.edu/ Africa_Studies/Newsletters/har_797.html

ICRC (International Committee of the Red Cross) (1997) Lethal floods create emergency in Somalia. Nando Media, Raleigh, $\mathrm{NC}_{\text {; }}$ available at www.nando.net

Jorgensen DL (1989) Participant observation: a methodology for human studies, Vol 15. Sage, London

Kerven C (1992) Customary commerce: a historical reassessment of pastoral livestock marketing in Africa. ODI Agr
Occas Pap 15. Overseas Development Institute, London

Kogan FN (1998) A typical pattern of vegetation conditions in southern Africa during El Niño years detected from AVHRR data using three-channel numerical index. Int $\mathrm{J}$ Remote Sensing 19:3689-3695

Krohn WB, Boone RB, Painton SL (1999) Quantitative delineation and characterization of hierarchical biophysical regions of Maine. Northeast Naturalist 6:125-150

Little PD, Brokensha DW (1987) Local institutions, tenure and resource management in East Africa. In: Anderson $\mathrm{P}_{\mathrm{r}}$ Grove R (eds) Conservation in Africa: people, policies and practice. Cambridge University Press, Cambridge, p 193-209

Lynn S (2000) Conservation policy and local ecology: Effects on Maasai land use patterns and human welfare in Northern Tanzania. MS thesis, Department of Range and Ecosystem Science, Colorado State University, Fort Collins

MacLeod J (1987) Ain't no making it. Westview Press, Boulder, $\mathrm{CO}$

McCracken G (1998) The long interview. Qualitative Research Methods Series 13. Sage Publications, London

Moran E, Brondizio E (1998) Land-use change after deforestation in Amazonia. In: Liverman D, Moran EF, Rindfuss RR, Stern PC (eds) People and pixels. Linking remote sensing and social science. National Academy Press, Washington, DC, p 94-120

Mwalyosi RBB (1992) Land-use changes and resource degradation in south-west Maasailand, Tanzania. Environ Conserv 19(2):145-152

Nabakwe R (1999) Tanzania may import food due to drought. Panafrican News Agency. Africa News Online, AllAfrica Global Media, Washington, DC; available at www. africanews.org/east/tanzania/stories/19990316_feat1.html

Nestel P (1986) A society in transition: developmental and seasonal influences on the nutrition of Maasai women and children. Food Nutrition Bull 18(1):2-18

Ngugi RK (1999) Use of indigenous and contemporary knowledge on climate and drought forecasting information in Mwingi District, Kenya. Report to UNDP, Nairobi

Nicholson SE (1993) An overview of African rainfall fluctuations of the last decade. J Clim 6:1463-1466

Nicholson SE (1994) Recent rainfall fluctuations in Africa and their relationship to past conditions over the continent. The Holocene 4(2):121-131

Omi PN, Wensel LC, Murphy JL (1979) An application of multivariate statistics to land-use planning: classifying land units into homogeneous zones. Forest Sci 25:399-414

Rigby P (1985) Persistent pastoralists. Zed Books, London

Rindfuss RR, Stern PC (1998) Linking remote sensing and social science: The need and the challenges. In: Liverman D, Moran EF, Rindfuss RR, Stern PC (eds) People and pixels. Linking remote sensing and social science. National Academy Press, Washington, DC, p 1-27

Sandford S (1983) Management of pastoral development in the Third World. Wiley, New York

Smith NM (1999) Maasai household economy: a comparison between the Loloiondo game controlled area and the Ngorongoro Conservation Area, Northern Tanzania. MA thesis, Department of Anthropology, Colorado State University, Fort Collins

Sperling L, Galaty JG (1990) Cattle, culture and economy: Dynamics in East African pastoralism In: Galaty JG, Johnson DL (eds) The world of pastoralism: herding systems in comparative perspective. Guilford Press, New York, p 69-98

Stern PC, Easterling WE (1999) Making climate forecasts matter. National Academy Press, Washington, DC 
Talle A (1987) Women as heads of houses: the organization of production and the role of women among pastoral Maasai of Kenya. Ethnos 52(I-ii):50-80

USGS (US Geological Survey) (1998) Global land 1-km AVHRR project. EROS Data Center, Sioux Falls, SD; available at edcwww.cr.usgs.gov/landdaac/1KM/1kmhomepage.html

USGS (1999) Dekad normalized difference vegetation index (NDVI) for Africa. EROS Data Center, International Program, Sioux Falls, SD; available at edcintl.cr.usgs.gov/

Submitted: February 15, 2000; Accepted: February 13, 2001 adds.adds.html

Washington Post (1998) El Niño's cruelty rains on Central, East Africa. March 2, 1998

Wilkinson L (1990) SYSTAT: the system for statistics. SYSTAT, Inc, Evanston, IL

Wishart D (1999) ClustanGraphics primer: a guide to cluster analysis. Clustan Limited, Edinburgh

World Meteorological Organization (1998) El Niño update 2/98. WMO, Geneva; available at www.wmo.ch/nino/ updat.html

Proofs received from author(s): October 30, 2001 